\title{
European Monetary Union. Convergences and Divergences in an Optimum Currency Area
}

\author{
Mihaela NECULITA ${ }^{\star}$, Adrian MICU ${ }^{\star \star}$
}

\begin{tabular}{l}
\hline \multicolumn{1}{c}{ A R T I C L E I N F O } \\
\hline Article history: \\
Accepted March 2020 \\
Available online May 2020 \\
\hline JEL Classification \\
F02, F15, F36, P35 \\
Keywords: \\
Disparities, Monetary integration, \\
Optimum currency area
\end{tabular}

\begin{abstract}
A B S T R A C T
Theory stated that a country should adhere to a monetary area if that country has about the same development level as member states. Otherwise, less developed countries will bear more pronouncedly the effects of asymmetric shocks that may occur in an integration zone. The reality exceeded far and away what the famous economist proved, the case of Greece being the example that put us forward how well we must be prepared for joining the EMU, the European Union itself roughening the financial rules for potential candidates. This paper aims to carry out an analysis of divergences and convergences in the Monetary European Union based on research on the various theories available in the literature and on the current situations of EMU members and non-member countries.
\end{abstract}

(c) 2020 EAI. All rights reserved.

\section{Introduction}

The Economic and Monetary Union is based on complying with the convergence criteria of the Maastricht Treaty for the accomplishment of the euro area.

Taking into account particularly each region in the EU, not all of them are optimum currency areas, namely their conditions do not allow the building-up of a common monetary area with several states, since the capital and the employment rate are inflexible. In 1997, 2 years before the EMU formation, the accession of Spain, Italy and Portugal to the euro area was questionable. This situation given depended largely on the situation in Germany. The condition was the following: if the German economy worsens until the EMU creation, and regional disparities get worse, then the entry of the 3 Mediterranean countries will be made earlier. According to statistics reviewed for Spain from 1992 to 1997, the growth rate of the GDP in Spain was not very impressive, being only $2.2 \%$ on the average. One of the criteria of the Maastricht Treaty is that by 1999, the budget deficit should not exceed 3\% of GDP. Spain already had 4.4\% in 1996 and had to reduce it over a 3 year-period. Moreover, Spain had a public debt of 70\% in 1997, contrary to the Maastricht provisions which imposed 60\%. (Sanchis 2011) It has been taken account of the situation in Italy, which had internal divergences between the South and the North, the differences being so large, that this instability worsened the situation in the regions when Italy joined the EMU.

The first countries to convert to the euro (the 11) managed in the medium and long term to maintain their banking market under the coordination of the European Central Bank. Greece joined later, but failed to maintain its economic stability after joining the EMU. This was due to both Greece and the European Union. Greece overestimated the achievement of the Maastricht convergence indicators, namely nominal convergence, and the European Union thought it would be able to support real convergence, even through a lower nominal convergence in relation to other member countries. What happened? Exactly what Paul Krugman(1993) and the asymmetric shock theory said. Greece was not economically prepared to back up any asymmetric shocks that might occur, and these had devastating effects in Greece. Greece was also one of the EMU member states that felt the effects of the eurozone crisis and the financial crisis 4 years after their triggering, the EU member states having to allocate funds to regulate the 2015 Greek crisis.

The medical crisis of 2019-2020 only proved that there are divergences both in the way things are perceived and in the way they are managed at the level of the EU and EMU member countries.

Nevertheless, the European Union, even though it was late with its actions, succeeded in due time to manage the divergences occurred, through a prompt financial support, and even more, through the consistency and continuity of its actions, both for the macroeconomic and microeconomic level. 


\section{Literature Review}

Since the establishment of EMU, several economic analysts have asked the question "Is the Economic and Monetary Union an optimum monetary area?". It is important to wonder whether the EMU and its member countries are truly an optimal monetary area, since, as defined by Andrew Broncier in 1999, the EMU is an economic space where the factors of production (here referring to the sources of capital, equity and employability rate, ie employment) are quite flexible and mobile in the event of an asymmetric economic shock. On the contrary, if these factors are not flexible enough, following an economic shock, referring to economic crises, another manner to combat or go through this economic and asymmetric shock is to be adjusted the interest rate.

In 1960, Mundell considered that is difficult to stabilize a region which uses fixed exchange rates if short-term capital is immobile, and more difficult under flexible exchange rates if capital is mobile. The fixedexchange-rate system is better in an area or areas where factors are mobile and the flexible-exchange-rate system is better for areas where factors are immobile.

Also he considered that the argument for flexible exchange rates is valid only if it is based on regional currency areas. The world should be divided into currency areas, according to him, only if the world could be divided into regions and the regions will apply for a policy of free mouvement of factors between them. (Mundell 1961)

Paul Krugman(1993) considered and is still considering that the eurozone is not an optimum currency area. Waltraud Schelkle in 2020 contradicts him and holds that no country or group of countries is an optimal monetary area in the first place because a region or a country always loses from a single monetary policy. However, countries can use fiscal, social and regulatory policies so as to overcome these difficulties. Waltraud believes that the adjustments made to the American dollar in the beginning, as well as to the financial system in the 19th century when criticizing the SME evolution are forgotten.

Both the less developed and developed countries incur high costs for foreign exchange transactions, and a single currency is not ideal for all countries and regions. Asymmetric shocks affect all types of countries and business cycles, so that a single monetary policy will always have negative effects for one of them. Notwithstanding, there are fiscal and social policies up to economies that can be used in exchange for the loss of monetary regulatory instruments.

Theoretically, labor mobility could replace the exchange rate fluctuations, but not to the same extent. The trade in goods and products is itself an indirect mobility of labor, capital moving where workers are. An OECD study finds that in the 2008 crisis, labor mobility in the European Union was higher than in the United States. However, this does not make the European Union an optimum currency area.

The exchange rates are reliable adjustment mechanisms being determined by financial asset markets, not by labor markets. For example, at the height of the 2008 financial crisis, capital flows turned to safety bonds. However, the theory of optimum currency areas ignores financial markets, insisting on monetary policy and central banks. Greenback in 1861-62, considered that the eurozone suffers from institutions that do not share risks between Member States. It took Americans more than 50 years in order to develop such an institution, and Europeans seem to neglect this.

\section{Eurozone}

How effective has the EMU actually proved to be? This was caused by the Great Recession in 2008. The global financial crisis of 2008 gradually turned into a "euro crisis" in 2010-2011. In 2018, the estimated value of GDP per capita in the eurozone was Eur 35,273,3136, 2.11\% higher than in 2017. In the table below we will show the difference between the GDP growth per capita both in the EU as a whole and in the euro area.

From the given figure we can see the differences in the relative percentage increase in all EU countries, and those in the eurozone. The eurozone seems to be much more affected than the EU during the crisis years, especially 2011-2014, but it was the one that recovered the fastest. The joining to the EMU of the new countries that have adopted the euro currency, with real convergence, has enabled GDP growth per capita, but on aggregate the entire European Union has also benefited from it, simply for the reason that the EMU is not a union separate from the EU, but a sub-union, a sub-category incorporated in the EU. (Trading Economics, 2019) 
Fig. 1 Comparative Study: Evolution of GDP per capita in the EU and EUROZONE countries in\%.

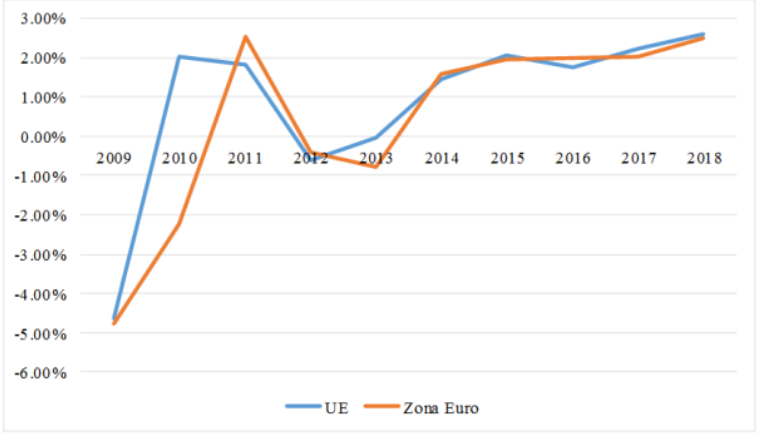

Source: World Bank Group, GDP growth (annual) European Union, available at https://data.worldbank.org/indicator/NY.GDP.MKTP.KD.ZG?locations=EU accessed on27.07.2019

When the global economic crisis set in in 2008, European and Eurozone governments advanced measures to back up and stimulate economies, enabling the increase in the limit of national budget deficits so as to enlarge demand and propel production.

Figure 2. Euro zone government deficit (\% of GDP)

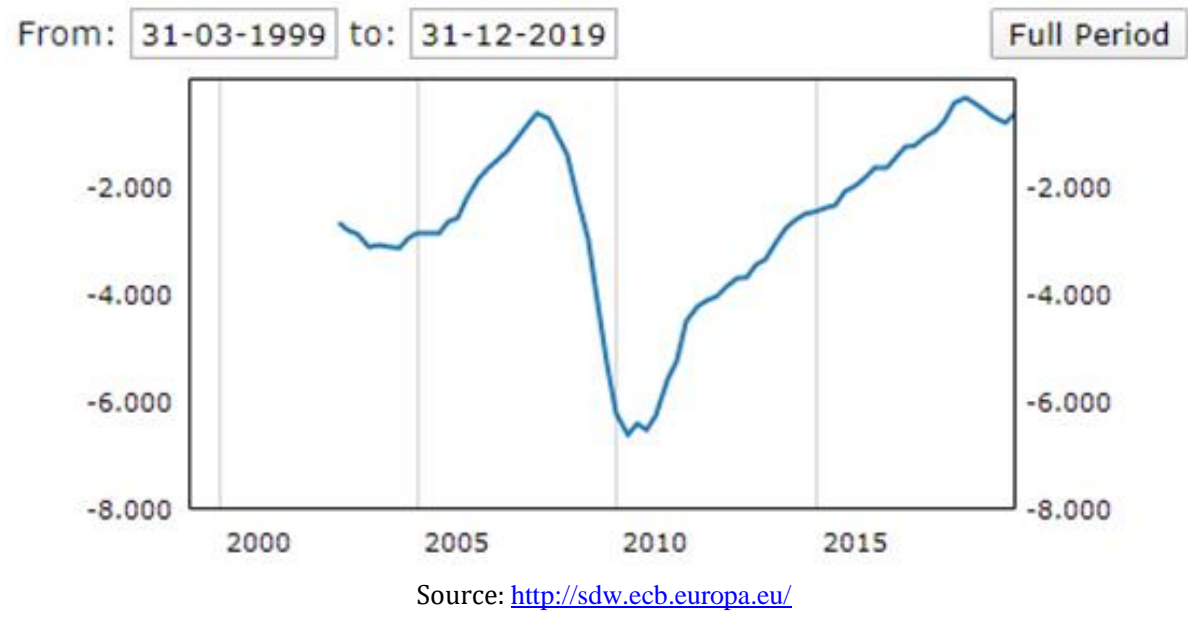

This has contributed to GDP growth and unemployment decrease. However, after 2010, the unemployment rate in the eurozone hightened until 2015, following which the policies of the union fueled the growth of places of employment. In 2020, due to the COVID-19 pandemic, the unemployment rate went up significantly in all European countries, greatly limiting labor mobility, which puts the cuerrency area in difficulty.

Figure 3. Euro zone Unemployment rate (as a \% of labour force)

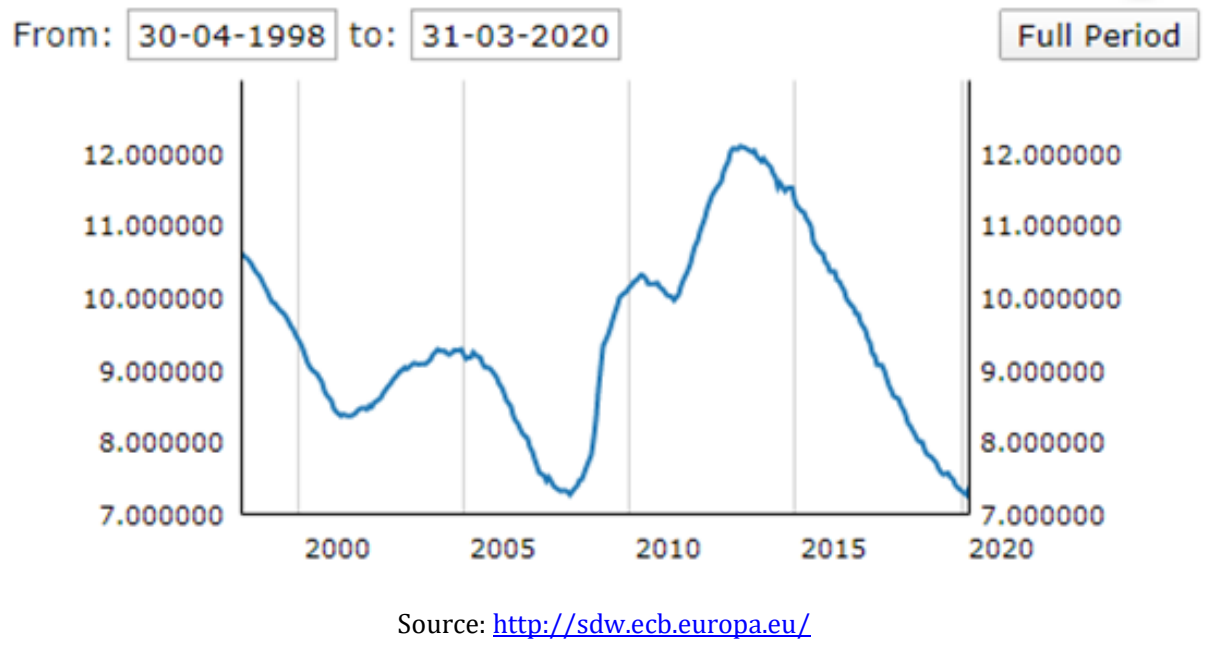


Following 2011, the Eurozone entered a recession again as it faced the debt crisis of the less developed Member States, a crisis that marked the existence of divergences at the EMU level. The best known example of divergence is Greece. The European Union has succeeded in avoiding the insolvency of the Greek state by granting it a loan of 110 billion euros and reducing its debt to other states proportionally. The average debt of the Eurozone countries goes beyond the average imposed by the Maastricht Treaty, namely $60 \%$ of GDP.

Figure 4. Euro zone government debt (\% of GDP)

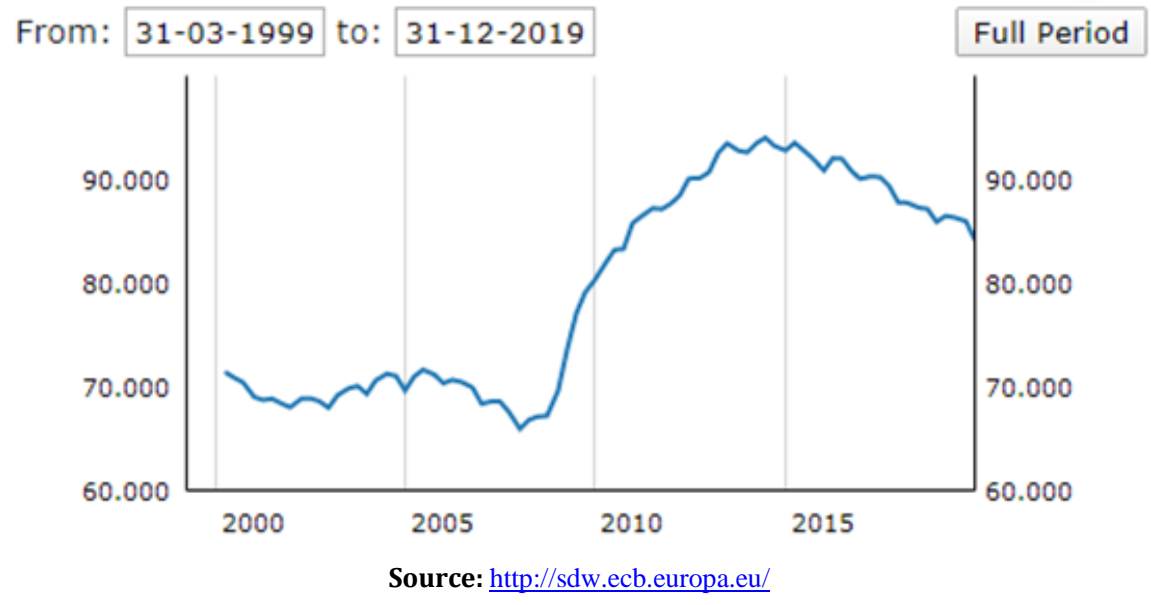

Recent studies have shown that there is a real convergence in the EMU level, a fact proven by the evolution of the inflation rate compared to GDP growth, which is by far one of the main divergences in the EMU. (CREMed, 2020)

Figure 5. Eurozone inflation rate

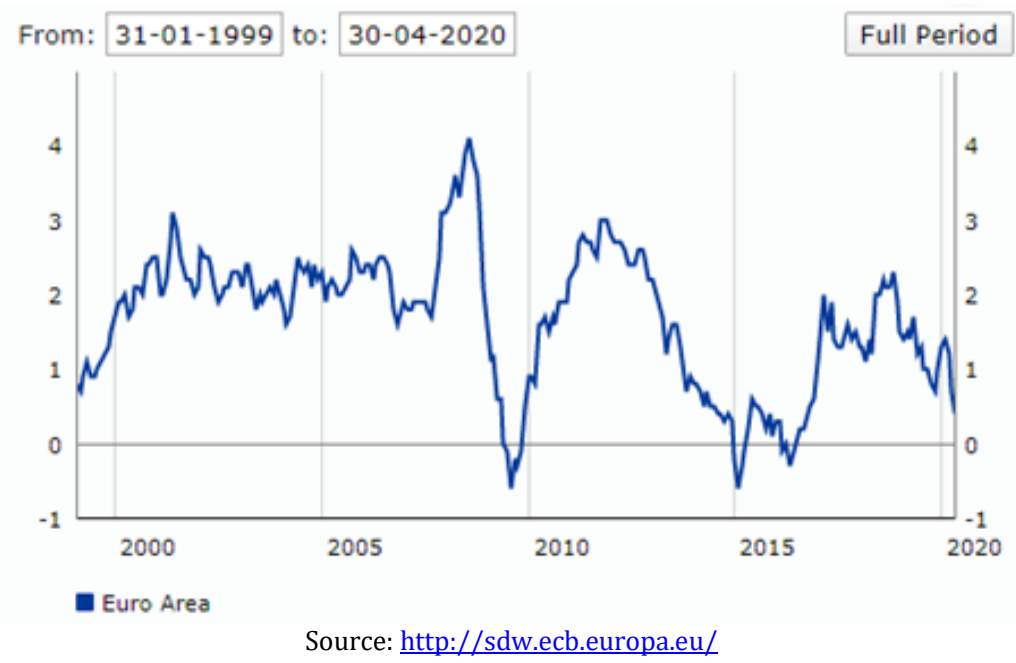

After switching to the euro, economists and politicians all track and analyze impact of the Euro (Ooghe H., Heylen F., Vennet R.V., Vermaut J, 2000). The representatives of the most important institutions in the EMU have readied a plan to support the economies and labor market in member countries, for the purpose of lowering divergences (Dombrovskis V., Moscovici P, 2014). 
Figure 6. Euro zone labour productivity

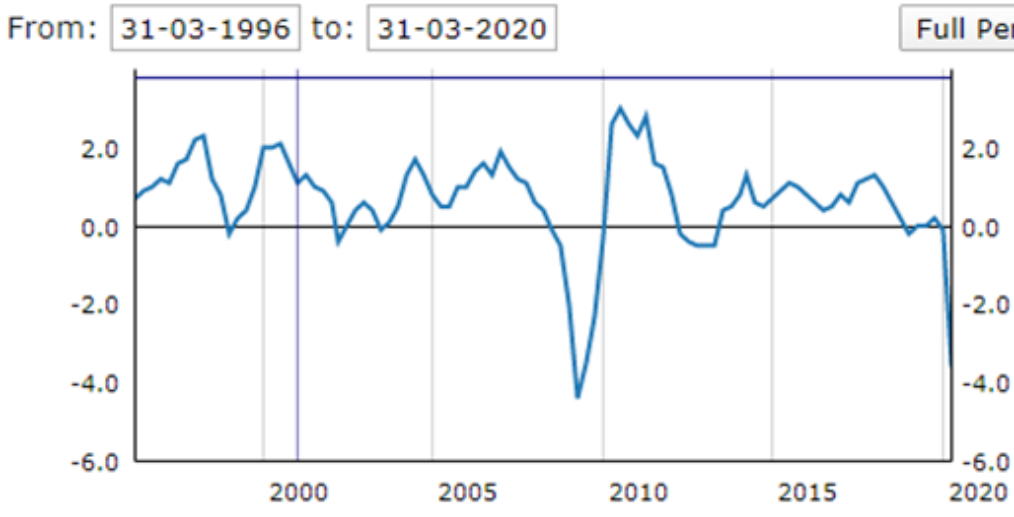

Source: http://sdw.ecb.europa.eu/

In addition to the problems caused by the unemployment rate, divergences were also at the level of labor productivity, without taking into account the future Brexit. Furthermore, the COVID-19 crisis showed what problems Italy was facing, but also showed the convergence of the EU decisions towards its members.

Again in relation to convergence, it has been shown that businesses in the eurozone are much more balanced than in the EU. However, following the crisis of 2008, the European Union and the EMU leaders established the European Stability Mechanism, which became operational in 2016. This mechanism supports the EMU member countries, but also candidate countries. In addition, it has been also set up an Eurogroup which, together with the European Central Bank, analyzes the disorders in the banking systems. The most recent proposal was to integrate Greece, Spain, Portugal, Cyprus, Slovenia, Romania and the Czech Republic into the ESM program of financial support of up to $€ 500$ billion maximum for economic stabilization. (Eichengreen, 2019)

Whether the EMU has proven or not its efficiency, statistics can best tell us through its macroeconomic indicators. If for example the unemployment rate in EMU countries of the EU doubled in the second wave of crisis with effects felt until 2015, by comparison, we can take the United States of America which went through the same stage of global economic crisis but managed to recover faster after the recession than most EU Member States. When the unemployment rate reached $10 \%$ in the US in October 2009, Americans thought this was intolerable. (Joseph, Stiglitz, 2016) The unemployment rate in the eurozone also reached $10 \%$ and remained so for a very long time.

Table 1. Comparative Study: Evolution of the unemployment rate in the eurozone countries, Non-EMU EU Member States and external to the EU (USA), before, during and after the Great Recession of 2008-09 and the

\begin{tabular}{|c|c|c|c|c|c|c|c|}
\hline & $\mathbf{2 0 0 7}$ & $\mathbf{2 0 0 8}$ & $\mathbf{2 0 0 9}$ & $\mathbf{2 0 1 0}$ & $\mathbf{2 0 1 1}$ & $\mathbf{2 0 1 4}$ & $\mathbf{2 0 1 8}$ \\
\hline Germany & $8.57 \%$ & $7.39 \%$ & $7.66 \%$ & $6.93 \%$ & $5.8 \%$ & $4.9 \%$ & $3.2 \%$ \\
\hline France & $8.01 \%$ & $7.48 \%$ & $9.08 \%$ & $9.28 \%$ & $9.20 \%$ & $10.20 \%$ & $8.90 \%$ \\
\hline Italy & $6.10 \%$ & $6.71 \%$ & $7.82 \%$ & $8.43 \%$ & $8.44 \%$ & $12.72 \%$ & $10.50 \%$ \\
\hline Spain & $8.57 \%$ & $13.79 \%$ & $18.66 \%$ & $20.11 \%$ & $22.56 \%$ & $23.6 \%$ & $14.3 \%$ \\
\hline Portugal & $8 \%$ & $7.61 \%$ & $9.40 \%$ & $10.89 \%$ & $12.70 \%$ & $13.9 \%$ & $7.1 \%$ \\
\hline $\begin{array}{c}\text { Great } \\
\text { Britain }\end{array}$ & $5.35 \%$ & $5.72 \%$ & $7.62 \%$ & $7.90 \%$ & $8.10 \%$ & $6.20 \%$ & $3.8 \%$ \\
\hline Romania & $6.41 \%$ & $5.78 \%$ & $6.85 \%$ & $7.27 \%$ & $7.40 \%$ & $6.78 \%$ & $4,0 \%$ \\
\hline USA & $4.63 \%$ & $5.88 \%$ & $9.30 \%$ & $9.60 \%$ & $8.90 \%$ & $6.24 \%$ & $3.86 \%$ \\
\hline
\end{tabular}

Source: IndexMundi, Countries Unemployment Rate, available at https://www.indexmundi.com/factbook/countries accessed on 04.07.2019

From the above data we can obviously see the big difference between the EMU Member States and other EU countries that have not joined the eurozone, compared to the USA and its behavior during and after the recession. What would be the causes of a high unemployment rate in the developed countries of the EU Spain, Portugal, France and Italy compared to Romania, one of the poorest EU Member States and why Germany has managed to scale down its unemployment rate so noticeably? Germany, the United Kingdom and the United States are three strong pillars in the world economy. They have succeeded in reducing the unemployment rate by implementing policies and reforms to balance again the economy. These 3 countries are also large industrial centers, so it was possible the creation of jobs for the population. On the other hand we have Romania which has managed to maintain a much lower unemployment rate even compared to developed countries in the eurozone - Italy, Spain, France, Portugal - based on mass migration of the population. According to statistics, the Romanian population has began to decline since 1992, together with 
the fall of communism and the opening of borders. Another important factor to be mentioned is the disparities in the EMU member countries. The EMU is not a perfect system and, following the crisis in the eurozone, the standards for adopting this currency were high through resolving the existing internal disparities.

The events that caused the crisis of the euro currency were symptoms of deeper problems in the structure of the eurozone: interest rates on bonds issued by Greece and several eurozone countries went high, being triggered a chain reaction that led to an increase in the inflation rate, unemployment rate and public debt, respectively, resulting in a major imbalance in trade relations. Some countries during the crisis could not get in any way access to financing and could not obtain the money needed to reimburse their debts. The EU came up with a solution, providing short-term funding, but with strong conditions. After the euro crisis bursted out in early 2010, the European leaders took 13 actions that, for the time beeing, seemed to calm the situation. In the post-Eurocrisis period, in addition to Greece's debts in 2015, other two crises had an economic impact: the migrant crisis and Brexit. These situations have affected the EU from a macroeconomic and microeconomic point of view. The macroeconomic impact was largely generated by the migrant crisis and the microeconomic one by Brexit. The migrant crisis, with many migrants managing to become refugees within some EU countries, including the EMU, was another factor for which the unemployment rate was influenced and was so high in 2014. Apart from the unemployment rate generated by the shock of the crisis, the inflation rate has also risen:

Table 2. Comparative Study: Evolution of the inflation rate in the eurozone countries, Non-EMU EU Member States and external to the EU (USA), before, during and after the Great Recession of 2008-09 and the Euro 2010-11

\begin{tabular}{|c|c|c|c|c|c|c|c|}
\hline & $\mathbf{2 0 0 7}$ & $\mathbf{2 0 0 8}$ & $\mathbf{2 0 0 9}$ & $\mathbf{2 0 1 0}$ & $\mathbf{2 0 1 1}$ & $\mathbf{2 0 1 4}$ & $\mathbf{2 0 1 8}$ \\
\hline Germany & $3.17 \%$ & $2.63 \%$ & $0.32 \%$ & $1.10 \%$ & $2.07 \%$ & $0.91 \%$ & $1.73 \%$ \\
\hline France & $1.49 \%$ & $2.82 \%$ & $0.09 \%$ & $1.53 \%$ & $2.11 \%$ & $0.51 \%$ & $1.85 \%$ \\
\hline Italy & $1.83 \%$ & $3.35 \%$ & $0.78 \%$ & $1.52 \%$ & $2.78 \%$ & $0.24 \%$ & $1.14 \%$ \\
\hline Spain & $2.78 \%$ & $4.09 \%$ & $-0.28 \%$ & $1.80 \%$ & $3.20 \%$ & $-0.15 \%$ & $1.23 \%$ \\
\hline Portugal & $2.45 \%$ & $2.59 \%$ & $-0.83 \%$ & $971.40 \%$ & $3.65 \%$ & $-0.28 \%$ & $0.99 \%$ \\
\hline $\begin{array}{c}\text { Great } \\
\text { Britain }\end{array}$ & $2.39 \%$ & $3.52 \%$ & $1 . \%$ & $2.49 \%$ & $3.85 \%$ & $1.45 \%$ & $2.29 \%$ \\
\hline Romania & $4.80 \%$ & $7.80 \%$ & $5.60 \%$ & $6.10 \%$ & $5.80 \%$ & $1.10 \%$ & $4.60 \%$ \\
\hline USA & $2.85 \%$ & $3.85 \%$ & $-0.34 \%$ & $1.64 \%$ & $3.16 \%$ & $1.62 \%$ & $2.44 \%$ \\
\hline
\end{tabular}

Source: Inflation EU Worldwide Inflation Data, Historic CPI Inflation Countries (yearly basis), available at

https://www.inflation.eu/inflation-rates/united-states/historic-inflation/cpi-inflation-united-states.aspx, accessed on 05.07.2019

It is remarked that the eurozone Member States have a very close inflation rate. The United Kingdom and Romania not being members of the eurozone, they have more autonomy over the local currency and the policies that can be implemented for market regulation, including the unemployment rate regulating. Being strongly connected with the EMU countries in terms of import or export of goods, buying foreign exchange on the market, etc., these countries could take advantage of fluctuations in the euro exchange rate during the crisis until 2015, the Great Britain strengthening its position in the union, and the USA making use of price differences in imports and exports. (Joseph, Stiglitz, 2016) In Romania, the inflation rate increased between 2014 and 2018 due to larger salaries, respectively the domestic costs went up and the income available to the consumers to spend more ran high. We notice that the stability of inflation is higher in the EMU states than in the United Kingdom and Romania, nevertheless the ratio of increase or decrease of the inflation rate is directly proportional for the bare reason that the mentioned countries are EU member states. Equally interesting is the evolution of the inflation rate in the USA in relation to the analyzed EU countries, considering the fact that the EU is an important trading partner of the United States. In this case, by analyzing the situation at Union level, the divergences among the countries whose economy is based on the euro, namely the countries of the Eurozone, and the countries that are in the process of getting real convergence in order to be able to join the EMU are highlighted, except for the states that have stated that they will not sign the Maastricht Treaty (Denmark, Sweden, Great Britain). In another train of thoughts, the euro must bring a closer economic and political integration, by helping Europe cope with the challenges faced by the region. (Weber, 2011) Although there are many factors contributing to weakening the EU's influence, the creation of the single euro currency without building a set of institutions that would enable a region as diverse as the EU to function efficiently with a single currency, has as consequence, first of all, the deepening of local differences.

Entering the euro has made easier the lives of traders and corporations. It has replaced 19 different currencies in 19 different countries with a single currency. Notwithstanding, the creation of a single currency also implied the creation of a Central Bank for the entire eurozone. The ECB determines interest rates that prevail throughout the entire area and acts as a lender of last resort for eurozone banks. The Central Bank fixes interest rates and can buy and sell currency. Both influence the exchange rate between the euro and 
other currencies, such as the dollar. Thus, at the beginning of 2016, the dollar-euro exchange rate was 0.92 , that is, if an American went to Europe with 100 dollars, he/she would receive 92 euros. A higher interest rate leads to a higher demand for the euro, and therefore to a higher exchange rate. The monetary policy is one of the most important instruments in the set of economic measures of the government. If the Central Bank wants to stimulate the economy, it lowers interest rates and makes credit more available, and lower interest rates lead to a lower exchange rate, making exports more competitive and discouraging imports. All countries engage in a certain form of public action, intervening in the market in order to forward macro-stability. Today, except in limited circumstances, the question arises as to whether it should be government intervention, how and where the government should act, considering the market imperfections. Unlike the United States, the EU and EMU institutions adopt regulations meant to protect and encourage corporate interests rather than regulations intended to protect the working class from corporate interests. However, the decisions made by the EU Euro19 institutions do not affect the whole of the European Union, 2 of the 28 Member States that have chosen not to adopt the euro, but they are also indirectly influenced. (Brunnermeier, 2016)

If we consider the Czech Republic, Slovakia, Poland and Romania, we can note that the evolution of the last decades and the historical context are similar. However, Slovakia managed to introduce the euro right at the time of the global financial crisis before Poland, Romania and its neighbor the Czech Republic. Even though the euro was entered in Slovakia, the GDP growth rate dropped sharply in 2009 by $-5.43 \%$, but recovered in 2010 with a GDP growth rate of 5.04\% (Sanchis, 2013). Before the introduction of the euro in Slovakia, Slovakia's economic height was in 2007 with a GDP growth rate of $10.06 \%$. Poland is the country with the most invariable rate of GDP growth. Non-euro countries recovered from the 2008-2009 crisis much faster than single currency countries. Again, this fact proves that the economic situation of countries with the same economic level in the same economic and monetary union is closely related and affects the entire area. (World Bank, 2017) Romania is the country with the highest inflation rate. A significant decrease in the inflation rate in Romania occurs between 2004 and 2007, 2007 being the year of Romania's accession to the EU. Germany had the most stable inflation rate, while Portugal recorded the highest inflation rate during the euro crisis in 2011. Practically the EMU countries are another union within a larger union, in other words the EMU is practically the union of "elite countries". (Overtveld, 2011)

\section{Conclusions}

It is known that if one of the EMU countries experiences economic shocks, the whole union will be affected. When the 19 countries reunite in a monetary union, each surrenders control over its interest rate.

The control transfer over exchange rates and interest rates can be very costly for a country. If countries with a common currency are similar enough, of course, all countries will be hit by the same shocks. - a reduction of the demand for products to China for example, or high demand for imports from the USA (Stell, 2013) In this way, the similar economic situation of the countries will lower the costs of the Economic and Monetary Union. When the Economic and Monetary Union will be complete, there is a possibility of deepening local disparities.

Using the same currency and without exchange rate, there is no way to adjust the exchange rate to make goods cheaper and more attractive. Whereas interest rate and exchange rate adjustments are among the most important manners through which economies accomodate in order to maintain full employment, the formation of the euro has given two of the most important instrument for ensuring this. Thus there are disparities among states in terms of imports and exports among countries. If there is an excess of imports, the exchange rate drops, making imports more expensive and exports more attractive. In case, for example, a country imported more than it exported, the imbalance could be corrected by diminishing the value of its currency, which would make exports more attractive and imports less attractive. With fixed exchange rates, this cannot happen. An excess of imports should be financed and, if the country with a trade deficit cannot borrow the money to be financed, then there will be a problem.

At the moment, also due to the COVID-19 crisis, there is no credible plan to resolve the problems of the eurozone, nor an action plan, apart from budgetary discipline and sanctions for states that fail to support it. Overall, the new model of "European economic governance" reflects the dominant opinion in Berlin and Paris with regard to the origin of the sovereign debt crisis of the European banking system crisis: excessive debt accumulation to the public and private sectors, resulting from persistent budget deficits and external deficits.(Mehnert-Meland, 2001)

It should be mentioned that France and Germany represent much of the opinion of the European institutions, thus being neglected many local disparities of the other Member States. Consequently, divergences are occurring throughout the eurozone.

What does the EMU do, or what should it do? For the time being, it should propose new regulations for Member States and candidate countries, since the economy of states depends on many other factors, not only economic but also social, external crises, divergences and disparities, each country pursuing its own interest. 


\section{Acknowledgement}

This paper was supported by the project "Excellence, performance and competitiveness in the Research, Development and Innovation activities at "Dunarea de Jos" University of Galati", acronym "EXPERT", financed by the Romanian Ministry of Research and Innovation in the framework of Programme 1 - Development of the national research and development system, Sub-programme 1.2 - Institutional Performance - Projects for financing excellence in Research, Development and Innovation, Contract no. 14PFE/17.10.2018.

\section{References}

1. Broncier A. (1999), Europa monetară SME, UME, monedă unică, Institutul European

2. Brunnermeier M.K., James H., Landau J.P (2016)., The Euro and the Battle of Ideas, Princeton University Press, New Jersey, pag. 17 - 18.

3. Dombrovskis V., Moscovici P.,(2014) Reuniunea la nivel înalt a zonei euro, Eurosummit, Ediția 9, Bruxelles, Belgia, pag.1.

4. Eichengreen B.,(2019) Convergence and Divergence in the EU: Lessons from Italy, Intereconomics, Vol. $54, \mathrm{nr} .1, \mathrm{pp} 31$ - 34 .

5. Joseph E. Stiglitz,(2016) The Euro. How a common currency threatens the future of Europe, W. W. Norton \& Company, New York, pag. 14

6. Krugman P. R. (1993): „Lessons of Massachusetts for EMU”, în Torres Francisco, Francesco Giavazzi (eds.), The Transition to Economic and Monetary Union, Cambridge University Press, Cambridge

7. Mehnert-Meland R.J.,(2001) Central Bank: Structures, Tasks, and Functions, Kluwer Law International, Ediția 16, Londra, Marea Britanie, pag. 50-51.

8. Mundell, R. (1960), The Monetary Dynamics of International Adjustment Under Fixed and Flexible Exchange Rate, The Quarterly Journal of Economics, Vol. 74, No. 2, pp. 227-257

9. Mundell, R. (1961) A Theory of Optimum Currency Areas, American Economic Review, vol. 51 No. 4 (Sep., 1961), pp. $657-665$

10. Ooghe H., Heylen F., Vennet R.V., Vermaut J.,(2000) The Economic and Business Consequences of the EMU, Springer Science+Business Media, LLC, , Belgia, pag 1.

11. Overtveld J., (2011)The End of the Euro: The Uneasy Future of the European Union, B2 Books, Chicago, pag. 201.

12. Sanchis i Marco M., Falacias, Dilemas y Paradojas.(2011) La Economia de Espana 1980 - 2010, Educacio, Valencia, pag. $201-221$.

13. Sanchis i Marco M., (2013)The Economics of the Monetary Union and the Eurozone Crisis, Springer, Valencia, pag. 20 - 23.

14. Stell B., (2013)The Battle of Bretton Woods, Princeton University Press, Princeton, pag. 54 - 58.

15. Schelkle W(2020) -Paul Krugman's argument that the eurozone is not an optimum currency area could be just as easily applied to the US, LSE, European Institute, https://blogs.lse.ac.uk/usappblog/2016/04/28/paul-krugmans-argument-that-the-eurozone-is-not-anoptimum-currency-area-could-be-just-as-easily-applied-to-the-us/accesed on 9.05.2020

16. Weber A.A., (2011)Challenges for Monetary Policy in the European Monetary Union, Federal Reserve Bank of St. Louis Review, Vol. 93, nr. 4 , pp $235-242$

17. Council of the European Union, Council Conclusions on a roadmap to complete the Banking Union, available at https://www.consilium.europa.eu/en/press/press-releases/2016/06/17/conclusions-on-banking-union/accessed on 10.05.2020

18. CREM - Centre for Economic Research on Mediterranean Countries, Convergencias y Divergencias economicas de los paises del sur del Mediterraneo con la Union Europea https://www.euromesco.net/institute/cermc-centre-for-economic-research-on-mediterraneancountries/accesed on 10.05.2020

19. IndexMundi, Countries Unemployment Rate, available at https://www.indexmundi.com/factbook/countries accessed on 04.07.2019

20. Inflation.Eu Worldwide Inflation Data, Historic CPI Inflation Countries (yearly basis), available at https://www.inflation.eu/inflationrates/united-states/historic-inflation/cpi-inflation-united-states.aspx, accessed on 05.07.2019

21. Trading Economics, Euro Area GDP Annual Growth Rate, available at https://tradingeconomics.com/euro-area/gdp-growth-annual accessed on27.06.2019

22. The World Bank, GDP growth (annual \%), available at https://data.worldbank.org/indicator/NY.GDP.MKTP.KD.ZG?display=graph\&end=2017\&locations=SK-PT-GB\&start=2004, accessed on05.16.2019

23. http://sdw.ecb.europa.eu/accessed on 15.05.2020 